
8 Research Square
Preprints are preliminary reports that have not undergone peer review.
They should not be considered conclusive, used to inform clinical practice, or referenced by the media as validated information.

\title{
Ethylene signaling transcription factor promote grape growth induced by exogenous carbon
}

\author{
Xin Zhao \\ Gansu Agricultural University

\section{Ying Wang} \\ Gansu Agricultural University \\ Wen-Fang Li \\ Gansu Agricultural University \\ Meng-Fei Li \\ Gansu Agricultural University \\ Zong-Huan Ma \\ Gansu Agricultural University \\ Mujitaba Dawuda \\ Gansu Agricultural University \\ Cun-Wu Zuo \\ Gansu Agricultural University \\ Ming-Yu Chu \\ Gansu Agricultural University \\ Bai-Hong Chen \\ Gansu Agricultural University \\ Juan Mao ( $\sim$ maojuan-81@163.com ) \\ Gansu Agricultural University
}

\section{Research article}

Keywords: Exogenous sugar, RNA-Seq, iTRAQ labeling, Ethylene signaling, ERF

Posted Date: June 20th, 2019

DOI: https://doi.org/10.21203/rs.2.10414/v1

License: (c) (i) This work is licensed under a Creative Commons Attribution 4.0 International License. Read Full License 


\section{Abstract}

Background The carbon can be converted into sugar which is not only important for plant growth and development, but also for plant signal transduction, especially in plant hormone response. The objective of this work was to build available genomic and proteomic resource to investigate the molecular mechanisms of exogenous carbon regulating plant growth and development. Results Grape (Vitis vinifera L. cv. 'Pinot Noir') plantlets cultured with exogenous carbon ( $2 \%$ sucrose, $1000 \mu \mathrm{mol} \cdot \mathrm{mol}-1 \mathrm{CO} 2$ and with both $2 \%$ sucrose and $1000 \mu \mathrm{mol} \cdot \mathrm{mol}-1 \mathrm{CO} 2$ were designated as S1, C0 and Cs, respectively). We used S0 (without sucrose, ambient CO2) as CK to analyze the differential expression genes and proteins induced by exogenous carbon. Through the transcriptomic and proteomic analysis, with pooled data for $\mathrm{Cs}, \mathrm{C} 0$ and $\mathrm{S} 1 \mathrm{compared}$ with $\mathrm{CK}, 70$ differentially expressed genes (DEGs) and 65 differentially expressed proteins (DEPs) were identified. Based on biological functions and physiological characteristics, we identified 8 DEGs and 2 DEPs related to ethylene signaling process. Amongst the DEGs we focussed on ERF TFs, including ERF5 (LOC100244353, LOC100247763, LOC100254616 and LOC100261260), ERF105 (LOC100249507 and LOC100259725), ERF2 (LOC100254640) and CTr (CTr7). Also, there were 2 DEPs related to ethylene metabolism, such as S-adenosylmethionine synthase 5 (SAM synthase 5; XP_002280106.1) and 1aminocyclopropane-1-carboxylic acid oxidase 2 (ACC oxidase 2; NP_001267871.1) were also identified. The transcriptome and proteome results suggested that exogenous carbon inhibits ethylene biosynthesis through ACC oxidase 2. Additionally, CTr7 and ERF5, which were up-regulated, are related to the ethylene signaling pathway. We speculate that exogenous carbon regulates plant growth through ethylene signaling pathways, but which inhibit ethylene biosynthesis. Conclusions Exogenous carbon regulates the expression of ethylene biosynthesis and signaling related genes, which may improve plant growth through the ethylene signaling pathway.

\section{Background}

Carbon is one of the vital substances of plant cytoskeleton and plays an irreplaceable role in plant growth and development process. The carbon is fixed by photosynthesis and converted into sugar [1]. The sugar plays pivotal roles in plant nutrient balance, optimum carbon to nitrogen ratio can either promote storage reserve mobilization and photosynthesis [2]. It is not only served as fuel supplying plant growth and a necessary compound for the synthesis of other substances, but also a signal which regulating plant growth and development [3, 4]. Plants use many sugar sensor proteins, such as Hexokinases (HXK), to interrelate light, and hormone signaling networks for controlling growth and development in response to the changing environment $[5,6]$. In plants, sugars including sucrose, glucose, fructose, and trehalose, and they have hormone like regulatory activities [7].

Sugar metabolism plays a pivotal role in governing the outcome of various kinds of plant-pathogen interactions and defense signaling [8, 9]. Sugar is also tightly interconnected with hormonal signaling pathways $[1,10]$. Gaseous phytohormone ethylene affects many aspects of plant growth. Ethylene is related to the following biological processes: regulation of leaf development, senescence, fruit ripening [1113], stimulation of germination and plant responses to biotic and abiotic $[14,15]$. Ethylene is a growth inhibitory hormone because ethylene sensitivity is negatively correlated with leaf growth [16]. Ethylene signal transduction is mainly related to ethylene receptor (ETR), constitutive triple response (CTR), ethylene insensitive (EIN) and Ethylene insensitive-like (EIL) [17-20]. The EIN/EIL proteins bind to upstream regions of ERF transcription factors (ERF TFs) to promote its expression in tissues. ERF TFs had been shown to be involved in various processes of plant development and response to biotic and abiotic stress [11,21]. Ethylene signal in plants is affected by environmental changes. Previous studies have shown that copper affects ethylene binding growth of ETR1 receptor in Arabidopsis thaliana [22]. Sugars have been proved to act as a signaling molecule to interact with ethylene signal, in regulating plant growth and development. Mutants displaying nonfunctional ethylene receptors (etr1, ein4) or alteration of signal transduction proteins (ein2 and ein3), are hypersensitive to sugar-mediated photosynthesis repression, while constitutive triple response 1 (ctr1), a negative regulator of ethylene signaling, is glucose insensitive [23-25]. ERFs, have been classified into AP2/EREBP-TF family, were identified as regulators of genes which related to plant growth $[21,26,27]$.

Molecular connection between ethylene and growth-regulatory pathways has been uncovered, we already know ethylene as inhibitor of leaf growth [16] and ERFs modulate transcription of a wide variety of genes which response to stress [28-30]. However, in higher plants the mechanism of exogenous carbon affects ethylene pathway remains unclear and whether exogenous carbon affects plant growth through ethylene pathway is uncertain. Although, the effects of ethylene on grape mostly focused on fruit ripening and postharvest [31, 32]. For example, postharvest ethylene treatment affects berry dehydration, polyphenol and anthocyanin conten [33].

While basic models have been suggested for regulatory mechanisms among these pathways, but sugar concentration, localization, or the nature of the sugar signal may differentially affect hormone signals and gene [34]. Therefore, this work aims to investigate the changes in ethylene related genes and proteins under the influence of exogenous carbon. Further study on how does ERFs response to exogenous carbon and regulates plant growth. 
We have revealed the effect of high $\mathrm{CO}_{2}$ concentration on photosynthesis of grape plantlets based on previous analysis [35]. However, the expression of genes, proteins and an understanding of plant growth regulated by exogenous carbon at molecular levels are still undisclosed. In this study, we used $2 \times 2$ experimental design in which sucrose and $\mathrm{eCO}_{2}$ were the main factor, to analyze the differential expression of ethylene-related genes and proteins in grape leaves induced by exogenous carbon through comparing with no carbon treatment, further to reveal the regulation of exogenous carbon on plant growth and development.

\section{Results}

\section{Exogenous carbon enhances plant biomass}

Grape plantlets in vitro were cultured for 25 days and exogenous carbon is supplied by $\mathrm{eCO}_{2}$ and sucrose. Those exogenous carbon treatments were compared with no carbon treatments. In agreement with what is known about the effect of exogenous carbon phenotype, our results showed that the leaf area, plantlet height and shoot fresh weight increased significantly in each treatment compared with CK (Fig. 1). Through the analysis of physiological indicators, exogenous carbon significantly affects plant growth. The fresh weight of the underground part, leaf area and plantlet height of grape plantlet in vitro were $0.07 \mathrm{~g}, 0.01 \mathrm{~g}$ and $4.63 \mathrm{~cm}^{2}$, respectively. These data were significantly lower than other treatments. The exogenous carbon significantly affected the fresh weight of aerial and underground part, but only caused changes in the dry weight of the aerial part of Cs. It had no significant effects on the dry weight of the underground part (Table 1).

\section{Analysis of transcriptomics}

To identify the molecular mechanisms responsible for increased plant growth with supply of exogenous carbon, comparison of gene transcription for plants grown with exogenous carbon and deficiency carbon was performed. A robust data set was collected after data processing, 46.50, 47.05, 46.89 and 47.08 million high-quality reads were obtained at Cs, C0, S1 and CK (Table S2). The bases content were $97.81 \%, 97.86 \%, 97.54$ and $97.04 \%$, respectively. The GC content were $46.33 \%$, 46.00\%, 46.00\%, 46.33\%, respectively (Table S2) .

To elucidate the mechanisms underlying the growth of plant supplied by exogenous carbon, genes expression in Cs, C0 and S1 were compared with CK. From 25,679 compiled genes, we identified 70 differentially expressed genes (DEGs) ( $P$-value<0.05, FC区2) when plants grown in exogenous carbon versus CK. Among those DEGs, 65 were up-regulated and 5 were down-regulated (Table 2). The fold change and $P$-value listed in Table S3.

Annotated DEGs were further categorised into GO terms and KEGG pathways. Through GO analysis of 70 DEGs identified in transcriptome, 58 genes (82.86\%) were annotated. Of these 70 DEGs, 12 were no match with SwissProt, KOG, KEGG or GO databases. The other 58 DEGs were able to match these databases and characterized. Those 58 DEGs with known function were further partitioned into 53 up-regulated (UR) and 5 down-regulated (DR). According to functional classification, the 58 DEGs were divided into 8 sections (Fig. 2). They were classified into 9 categories: primary metabolism (15.52\%), transcription (15.52\%), cell morphogenesis (10.34\%), biosignaling (3.45\%), secondary metabolism (18.97\%), translation/protein (12.07\%), transport (15.52\%), transcription/polynucleotide biosynthesis (1.72\%) and stress tolerance (6.90\%) (Fig. 2).

\section{Analysis of proteomics}

To better dissect the molecular regulated network in grape plantlets in vitro response to exogenous carbon, we utilized iTRAQ labeling strategy to perform quantitative proteomics and analyze the global protein changes in exogenous carbon supplied plants. From the pooled data for $\mathrm{Cs}, \mathrm{CO}$ and S1 compare with CK, 3047 unique proteins were identified. There were 65 differentially expressed proteins (DEPs) identified from Cs, C0 and S1 compare with CK ( $P$-value $<0.05, \mathrm{FC} \otimes 1.4$ or FC $<5 / 7)$, including 7 UR proteins and 58 DR proteins (Table 3). The fold change and $P$-value listed in Table S4.

Among these DEPs, 17 DEPs could not match with the UniParc and RefSeq database. Therefore, the biological functions of these proteins are not clear. The other 48 DEPs matched with proteins of known function to be characterized in the UniProt database, but 7 DEPs functions might still unclear (Fig. 3). Based on biological functions, the 41 DEPs were classified into 7 categories: primary metabolism (25.64\%), secondary metabolism (41.03\%), energy (2.56\%), bio-signaling (7.69\%), translation (7.69\%) and transport (7.69\%) (Fig. 3). 


\section{The combined analysis of exogenous carbon affects plant ethylene signaling}

Using transcriptome and proteomics analysis, we identified 8 DEGs and 2 DEPs related to ethylene signaling process (Fig. 4). These DEGs were ERF transcription factors: ERF5 (LOC100244353, LOC100247763, LOC100254616 and LOC100261260), ERF105 (LOC100249507 and LOC100259725), ERF2 (LOC100254640) and CTR (CTR7) (Table 4). Differential expression of ethylene pathway related genes was confirmed by qRT-PCR and their relative expression level was consistent with FPKM values fold change observed from transcriptional analysis, only 2 genes analyzed by qRT-PCR, i.e., METK5 and ACO2 under S1 treatment were not consistent with our RNAseq data (Table 4).

Although previous transcriptome analysis revealed that exogenous carbon associated with ethylene signaling, there were 2 DEPs related to ethylene metabolism: S-adenosylmethionine synthase 5 (SAM synthase; XP_002280106.1) and 1-aminocyclopropane-1-carboxylic acid oxidase 2 (ACC oxidase 2; NP_001267871.1). We identified the SAM synthase 5 up-regulated but ACC oxidase 2 down-regulated in exogenous carbon treatments (Table 4).

\section{DEGs associated with plant growth}

DEGs involved in primary metabolism: There were 9 DEGs related to primary metabolism, 7 up-regulated in Cs, C0 and S1 treatments, 2 down-regulated in exogenous carbon treatments. Those 9 DEGs could divide into 5 categories: nucleoside (LOC100242429), carbohydrate catabolic process (LOC100244286, LOC100247598 and LOC100252971), carbohydrate metabolic process (LOC100263433), amino acid metabolic (LOC100254909), lipid (LOC100266479, LOC100257217 and LOC100266419). Two of the 3 genes related to lipids were down-regulated (Fig. 5).

DEGs involved in stress tolerance: DEGs that were associated with plant stress tolerance including oxidative stress (LOC100255112), biotic stress (LOC100255226) and abiotic stress (LOC100262206 and SODCP). Under the influence of exogenous carbon, 3 genes were up-regulated and 1 gene (SODCP) down-regulated (Fig. 5).

DEGs involved in secondary metabolism: Compared with the control, 11 DEGs were differentially expressed in the secondary metabolic pathway. Eleven genes can be clustered into 3 groups: glutathione metabolic (LOC100242506 and LOC109122826), proteolysis (LOC100265220 and LOC100253211) and flavonoid biosynthetic (LOC100250788, LOC100852631, LOC100249367, LOC109121674, LOC100243852, LOC100255939 and LOC100266388). Of these DEGs, only 1 gene related to flavonoid biosynthetic was down-regulated in exogenous carbon treatment, and the others were up-regulated (Fig. 5).

\section{DEPs associated with plant growth}

Out of 11DEPs associated with primary metabolism, all those DEPs directly or indirectly catalyze sugar biosynthesis. There were 7 DEPs were related to the carbohydrate metabolic process (NP_001267891.1, NP_001267896.1, NP_001268153.1, XP_002276351.1, XP_002276777.1, XP_002282132.1 and XP_003635074.1). There were 2 DEPs were related to the tricarboxylic acid cycle (XP_002278138.1 and XP_002284064.1). There were 2 DEPs were related to sucrose metabolic process (XP_002271896.1 and XP_002270414.1). However, all the proteins associated with primary metabolism were up-regulated in CK and down-regulated in treatments (Fig. 6).

With exogenous carbon supply, proteins that participate in environmental stress are differential expression. Indeed, 16 DEPs were observed up-regulated in CK, these DEPs could be divided into three categories: defense response (NP_001267956.1, XP_002274242.1, XP_002274535.1, XP_002283780.1, XP_002284278.1, XP_002281607.1, XP_002282917.2 and XP_002283030.1), oxidative stress (NP_001268098.1, XP_002269918.1, XP_010651402.1, XP_010656112.1 and XP_002285723.1) and glutathione metabolic process (XP_002262842.1, XP_002280532.1 and XP_002278339.1) (Fig. 6). Interestingly, 1 DEP in glutathione metabolism pathway was upregulated in exogenous carbon treatment.

All of 3 DEPs that are associated with secondary metabolism were to be down-regulated under exogenous carbon supply. These DEPs can be classified into three categories: biosynthetic process (NP_001268064.1), mucilage biosynthetic process (XP_002269677.1), phenylpropanoid metabolic process (XP_002281799.1) (Fig. 6).

\section{Discussion}




\section{Exogenous carbon promotes plant growth through ethylene signaling}

Although SAM synthetase 5 was up-regulated under exogenous carbon treatment, ACC oxidase 2 was down-regulated. The final step in ethylene biosynthesis is catalysised by ACC oxidase [36]. ACC oxidase was referred to as ethylene forming enzyme [37]. However, in sugar-free control, ACC oxidase expression was up-regulated, this change will likely producing additional ethylene, which affected the no normal growth of plants and resulted in plant slower growth (Fig 7). In the absence of exogenous glucose, plant growth is restricted to the seedling stage even after culturing on MS medium [38]. Ethylene is a growth inhibitory hormone [16]. In Arabidopsis, excess ethylene would cause plant dwarfism and slows down growth $[39,40]$. Therefore, those plantlets which lack of exogenous sugar grows slowly may also be affected by endogenous ethylene.

In the process of ethylene signaling, copper ions likely play a role in ethylene binding and transported by RAN1 [22, 41], it serves as a cofactor for ethylene binding and is required for proper biogenesis of the receptors. The results implicate that exogenous carbon, especially $\mathrm{eCO}_{2}$ could enhance the $C T r 7$ expression. We speculate that $\mathrm{eCO}_{2}$ may regulate ethylene signal by affecting the transport of copper ions.

ERF, which is involved downstream of ethylene signaling, is involved in various processes of plant development [11, 21] and different stress responses $[42,43]$. However, we observed that ERF expression increased with exogenous carbon supply. ERF could promoters of secondary target genes, which contains GCC box, such as chitinase [44]. Therefore, we speculated that exogenous carbon can regulate the expression of other genes through ERF. The ERF transcription factors can be classified as activating-or repressing-transcription factors, with ERF2 and ERF4 being activators and ERF3 being a repressor of transcription [45]. ERF5 is an activator of transcription and interacts with multiple proteins, such as ERF6, ERF8, and SCL13 [46, 43]. ERFs belong to the AP2/EREBP transcription factor family [26], which can strongly bind a wide range of cis-regulatory elements, in the promoter of target genes [47, 48]. As the final response gene in ethylene signaling pathway, basic endochitinase precursor (NP_001267891.1) changes, proving its relation to ERF [43]. Overexpression of $E R F$ enhances resistance to bacterial and fungal pathogens [49]. Under exogenous carbon treatment, which genes interact with ERF remains to be illustrated. In addition, some ERF enhances the activities of ACC oxidase, thereby promoting ethylene synthesis and signal transduction [50,51]. However, some ERFs also repress of ACC oxidase activities to prevent ethylene biosynthesis [52-54]. In our study, we speculate that ERF5 exhibits an inhibitory effect on ACC oxidase.

After analysis of transcriptome and proteome data, we speculated that exogenous carbon regulates plant growth through ethylene signaling pathways that inhibit ethylene biosynthesis. The expression of ERF5 increased under the action of exogenous carbon may further promoting plant growth. However, mechanisms on how exogenous carbon affects ERF5 and which genes are affected by ERF require further study. ERF TFs likely play a major role in these regulatory pathways. Identification of their direct target genes will be helpful and will improve our understanding of their sometimes contradictory roles in plant growth.

\section{Exogenous carbon affects Primary metabolism}

Many DEGs and DEGs are involved in the process of primary metabolism under exogenous carbon treatment. Compared with CK, betaglucosidase was up-regulated but chitinase was down-regulated. However, the mechanism of tyrosine/DOPA decarboxylase and xyloglucan galactosyl transferase MUR3 needs further study. These DEPs can be categorized into carbohydrate metabolic process, sucrose metabolic process and tricarboxylic acid cycle. SUS is a sucrose degrading enzyme in plants [2]. SUS produces more energy than INV during metabolism [55]. Probably because of this reason, the expression of SUS was up-regulated in control and could produce additional energy to supply plants without sugar. Additionally, exogenous fructose significantly reduces leaf and root SUS activity [56], so we speculate that exogenous carbon may be converted into fructose in leaves to reduce SUS activity. Supported by exogenous carbon, the leaves were used as the source organs for energy conversion through photosynthesis. However, under sugar free treatment, SUS activity was high and the leaves sank.

Glyceraldehyde-3-phosphate dehydrogenase is a glycolytic enzyme [57]. Citrate synthase is a key enzyme of the citric acid cycle that provides energy for cellular function [58]. These two proteins were significantly up-regulated under sugar free treatment. This result suggests that carbon fixed by photosynthesis is further metabolized through glycolysis and tricarboxylic acid cycling in the plant of absence sugar. The light-harvesting complex-like protein was up-regulated under exogenous carbon treatment, indicating that exogenous carbon can promote photosynthesis. Carbohydrate repression of photosynthetic gene expression can only be observed under low nitrogen conditions [4]. 


\section{Exogenous carbon affects second metabolism through ethylene signaling}

Plant secondary metabolism and its metabolites are related to plant function and growth [59]. Different environmental conditions regulate the production of secondary metabolites, such as water, flavonoids $[60,61]$ and others. Under exogenous carbon treatment, the secondary metabolism related genes and proteins expressed differently, especially flavonoid synthesis, phenylalanine ammonia-lyase (PAL) and chalcone synthase (CHS).

PAL, the important enzyme linking the secondary metabolism to primary metabolism, participates in the biosynthesis of flavonoids, lignins, stilbenes and many other compounds [62]. PAL can be induced by some environmental conditions, such as sunlight, mechanical wounding, methyl jasmonate and salicylic acid [63-66]. Sugar is also related to PAL activity. El-Awady [67] indicated that sucrose can induce PAL. However, PAL induction is repressed by glucose [68]. Ethylene is involved in the signaling pathways modulating the production of secondary production in plants cells [69]. Under exogenous carbon, ERF up-regulates the expression of PAL and PAL increased. This finding suggests that exogenous carbon affecting secondary metabolism in leaves is associated with ethylene signaling.

CHS is the first enzyme of the flavonoid biosynthesis pathway [70]. CHS can be induced by sugar [71]. The expression of CHS was not significant compared with $\mathrm{CK}$, but the $\mathrm{CHS}$ expression was significantly up-regulated under exogenous carbon treatment. The ethylene antagonist 1-MCP can inhibit CHS [72]. Exogenous ethylene can stimulate genes which are related to anthocyanin biosynthesis increase, such as CHS [73]. Ethylene signaling is associated with secondary metabolism [69]. In transcriptome data, the expression of genes related to flavonoid synthesis was up-regulated. This result indicates that exogenous carbon may promote the synthesis of flavonoids in plants by ethylene signaling. The mechanisms by which exogenous carbon cause changes $\mathrm{CHS}$ and $\mathrm{CHS}$ remain to be further studied.

\section{Conclusions}

This study reveals that exogenous carbon may regulates plant growth through ethylene pathway. Exogenous carbon affects plant growth by inhibiting ethylene biosynthesis and ethylene signaling through ACC oxidase 2, CTR and ERF. However, the increased expression of ERF5 under the action of exogenous carbon may promote plant growth. Without exogenous carbon supplied, the carbon fixed by photosynthesis will further metabolise through glycolysis and tricarboxylic acid cycling. Exogenous carbon can also promote the synthesis of flavonoids in plant.

\section{Methods}

\section{Plant materials and growth conditions}

The 'Pinot Noir' ( $V$. vinifera $L$.) samples were collected from the main producing area of Gansu Province, northwest China. The plantlets material was propagated from branches of adult mother plants. The voucher specimens of grape were deposited in the Fruit Tree Physiology and Biotechnology Laboratory, College of Horticulture, Gansu Agricultural University. Those plantlets were grown at $26^{\circ} \mathrm{C}$, at a $16 \mathrm{~h}$ light and $8 \mathrm{~h}$ dark cycle. The average photosynthetic photon flux was $120 \mu \mathrm{mol} \cdot \mathrm{m}^{-2} \cdot \mathrm{s}^{-1}$. One climate chamber $\left(\mathrm{PQX}-430 \mathrm{D}-\mathrm{CO}_{2}\right)$, which have TC-5000 (T) intelligent $\mathrm{CO}_{2}$ controller to regulate $\mathrm{CO}_{2}$ concentration at approximately $1000 \mu \mathrm{mol} \cdot \mathrm{mol}^{-1}$. The other chamber was maintained with current atmospheric $\mathrm{CO}_{2}$. After conventional propagation, nodal segments (average $20 \mathrm{~mm}$ in length) with leaves and with two axillary buds were cultured on modified B5 solid medium containing $0.1 \mathrm{mg} \cdot \mathrm{L}^{-1} \mathrm{IAA}, 50 \mathrm{~mL}$ of medium was taken in $150 \mathrm{~mL}$ erlenmeyer flasks, which was using gas-permeable membrane sealing. Then put those explants materials into two climate chambers for treatment. Meanwhile, explants were treated by $\mathrm{eCO}_{2}\left(1000 \mu \mathrm{mol} \cdot \mathrm{mol}^{-1}\right)$ and sucrose after inoculation for 25 days. We use sucrose and $\mathrm{CO}_{2}$ to provide exogenous carbon. Growth occurred under following four conditions: $\mathrm{Cs}$ : modified B5 solid medium containing $0.1 \mathrm{mg} \cdot \mathrm{L}^{-1}$ IAA with $2 \%$ sucrose and $\mathrm{eCO}_{2}$; $\mathrm{C}$ : modified $\mathrm{B} 5$ solid medium containing $0.1 \mathrm{mg} \cdot \mathrm{L}^{-1} \mathrm{IAA}$ without sucrose but with eCO ${ }_{2}$; S1: modified B5 solid medium containing $0.1 \mathrm{mg} \cdot \mathrm{L}^{-1} \mathrm{IAA}$ with $2 \%$ sucrose, ambient $\mathrm{CO}_{2}$; SO: modified $\mathrm{B} 5$ solid medium containing $0.1 \mathrm{mg} \cdot \mathrm{L}^{-1} \mathrm{IAA}$ without sucrose, ambient $\mathrm{CO}_{2}\left(380 \pm 40 \mu \mathrm{mol} \cdot \mathrm{mol}^{-1}\right)$, we use SO as $\mathrm{CK}$ to analyze the differential expression genes and proteins induced by exogenous carbon. Each treatment had three biological replicates with 15 plantlets per replicate.

Plantlet leaves were harvested at 25 days after inoculation. Fully expanded younger leaves (the third and fourth functional leaves) of the cultivars were sampled. Three independent biological replicates were acquired. Each replicate was collected from more than 10 randomly selected plantlets. The leaf samples were transferred immediately to liquid nitrogen and stored at $-80^{\circ} \mathrm{C}$ for transcriptome and iTRAQ analyses. 


\section{Growth parameters}

The in vitro growth characteristics assessed after 25 days were as follows: fresh weight of aerial parts $(\mathrm{g})$, fresh weight of underground part (g), dry weight of aerial parts $(\mathrm{g})$, dry weight of underground part $(\mathrm{g})$, total dry mass $(\mathrm{g})$, average leaf area $\left(\mathrm{cm}^{2}\right)$ and plantlet height $(\mathrm{cm})$.

\section{RNA isolation and library preparation for transcriptome analysis}

Total RNA was extracted using the mirVana miRNA Isolation Kit (Ambion). Each sample was evaluated using the Agilent 2100 Bioanalyzer (Agilent Technologies, Santa Clara, CA, USA) as as described previously [35].

\section{Analysis of RNA-Sequencing data}

Raw microarray data was acquired and analyzed as previously described [35]. Raw data (raw reads) were filtered into clean reads using NGS QC Toolkit [74]. Then the clean reads were mapped to reference genome using hisat2 [75]. A differentially expressed gene was defined as a variation in the gene expression test with a $P$-value $<0.05$ and a fold change $(\mathrm{FC})>2$ or $\mathrm{FC}<0.5$. Functional gene classification was performed using the UniProtKB/Swiss-Prot database.

\section{Protein extraction, digestion and ITRAQ labeling}

Total proteins were extracted from the leaf tissue of grape in vitro as previously described [35]. The protein concentration was quantified by BCA method [76] and the protein purity was detected by SDS-PAGE [77]. Protein digestion was performed according to the FASP procedure [78].

\section{RP chromatography separation and Mass spectrometry analysis}

iTRAQ labeled peptides were fractionated by RP chromatography separation using the 1100 HPLC System (Agilent). The specific process as described previously [35].

\section{Protein identification and function annotation}

Protein identification was performed using the Proteome DiscovererTM 2.2 (Thermo, USA) with the $V$. vinifera genome protein database. Search parameters were chosen as reported by Zhao et al. [35]. The NCBI and UniProt databases were selected for validation and annotation of the protein sequences. GO annotation for the identified proteins was assigned according to UniProt database (http://www.uniprot.org).

\section{qRT-PCR analysis}

The 10 genes related to ethylene pathways were verified by qRT-PCR. Primer sequences used for qRT-PCR are provided in Table S1.

\section{Statistical analysis}

Data are expressed as the mean \pm SD from three independent biological replicates. Significance was determined via one-way analysis of variance (ANOVA).

\section{Abbreviations}

DEGs: Differentially expressed genes; DEPs: Differentially expressed proteins; $\mathrm{eCO}_{2}$ : Elevated $\mathrm{CO}_{2}$ concentration; GO: Gene ontology; KEGG: Kyoto encyclopedia of genes and genomes; CTR: Constitutive triple response; ERF: Ethylene response factor; SAM synthase: Sadenosylmethionine synthase; ACC oxidase: 1-aminocyclopropane-1-carboxylic acid oxidase; SUS: Sucrose synthase; IAA: Indole acetic 
acid; PAL: phenylalanine ammonia-lyase; CHS: chalcone synthase; ETR: ethylene receptor; EIN: ethylene insensitive; EIL: Ethylene insensitive-like

\section{Declarations}

\section{Ethics approval and consent to participate}

Not applicable.

\section{Consent to publish}

Not applicable

\section{Availability of data and materials}

The datasets generated and analysed during the current study are available from the corresponding author on reasonable request.

\section{Competing interests}

The authors declare that they have no competing interests.

\section{Funding}

This research was financially supported by the Discipline Construction Funds for Horticulture, Gansu Agricultural University (GAU-XKJS2018-226) and the Science and Technology Major Project of Gansu Province (18ZD2NA006). The funding agencies provided only the experimental cost and publication fee for this work. However, the experimental design and data collection and analysis were managed by the contributing authors.

\section{Authors' contributions}

BHC and JM designed the experiments. XZ and YW conducted the experiments. XZ, WFL and MFL analyzed the data. ZHM and CWZ managed the materials. XZ and WFL wrote the manuscript. MYC and MD previewed and revised the English of manuscript. All authors read and approved the manuscript.

\section{Acknowledgements}

Not Applicable.

\section{Additional files}

Additional files 1: Table S1. Sequences of primer employed in qRT-PCR analysis.

Additional files 2: Table S2. Summary of sequencing data of 'Pinot Noir' plantlet in vitro.

Additional files 3: Table S3. The description and Fold Change of DEGs from exogenous carbon treatments compared with CK. Additional files 4: Table S4. The description and Fold Change of DEPs from exogenous carbon treatments compared with CK.

\section{References}

1. Ljung K, Nemhauser JL, Perata P. New mechanistic links between sugar and hormone signalling networks. Curr Opin Plant Biol. 2015;25:130-137. 
2. Martin T, Oswald $\mathrm{O}$, Graham IA. Arabidopsis seedling growth, storage lipid mobilization, and photosynthetic gene expression are regulated by carbon:nitrogen availability. Plant Physiol. 2002;128(2):472-481.

3. Ruan YL. Sucrose Metabolism: Gateway to diverse carbon use and sugar signaling. Annu Rev Plant Biol. 2014;65:33-67.

4. Lastdrager J, Hanson J, Smeekens S. Sugar signals and the control of plant growth and development. J Exp Bot. 2014;65(3):799.

5. Moore B, Zhou L, Rolland F, Hall Q, Cheng WH, Liu YX, Hwang I, Jones T, Sheen J. Role of the Arabidopsis glucose sensor hxk1 in nutrient, light, and hormonal signaling. Science. 2003;300(5617):332-336.

6. Li L, Sheen J. Dynamic and diverse sugar signaling. Curr Opin Plant Biol. 2016;33:116-125.

7. Yu SM, Lo SF, Ho THD. Source-Sink Communication: Regulated by Hormone, Nutrient, and Stress Cross-Signaling. Trends Plant Sci.2015;20(12):844-857.

8. Kanwar P, Jha G. Alterations in plant sugar metabolism: signatory of pathogen attack. Planta. 2018;249(2):305-318.

9. Qi T, Song S, Ren Q, Wu D, Huang H, Chen Y, Fan M, Peng W, Ren C, Xie D. The jasmonate-ZIM-Domain proteins Interact with the WDRepeat/bHLH/MYB complexes to regulate jasmonate-mediated anthocyanin accumulation and trichome initiation in Arabidopsis thaliana. Plant Cell. 2011;23:1795-1814.

10. Li P, Zhou H, Shi X, Yu B, Zhou Y, Chen S, Wang Y, Peng Y, Meyer RC, Smeekens SC. The ABI4-Induced Arabidopsis ANAC060 transcription factor attenuates $A B A$ signaling and renders seedlings sugar insensitive when present in the nucleus. Plos Genet. 2014(3);10:e1004213.

11. Dubois M, Skirycz A, Claeys H, Maleux K, Dhondt S, Stefanie DB, Bossche RV, Milde LD, Yoshizumi T, Matsui M, Inzé D. Ethylene response factor 6 acts as a central regulator of leaf growth under water-Limiting conditions in Arabidopsis. Plant Physiol. 2013;162(1):319-332.

12. Shahri WTI. Flower senescence-strategies and some associated events. Bot Rev. 2011; 77(2):152-184.

13. Bakshi A, Shemansky JM, Chang C, Binder BM. History of research on the plant hormone ethylene. J Plant Growth Regul. 2015;34(4):809-827.

14. Jan K, Staden JV. Interaction of karrikinolide and ethylene in controlling germination of dormant Avena fatua L. caryopses. Plant Growth Regul, 2012;67(2):185-190.

15. Cao Y, Song F, Goodman RM, Zheng Z. Molecular characterization of four rice genes encoding ethylene-responsive transcriptional factors and their expressions in response to biotic and abiotic stress. J Plant Physiol. 2006;163(11):1167-1178.

16. Dubois M, Lisa VDB, Inzé D. The pivotal role of ethylene in plant growth. Trends Plant Sci. 2018;23(4):311-323.

17. O'Malley RC, Rodriguez FI, Esch JJ, Binder BM, O'Donnell P, Klee HJ, Bleecker AB. Ethylene-binding activity, gene expression levels, and receptor system output for ethylene receptor family members from Arabidopsis and tomato. Plant J. 2005;41(5):651-659.

18. Kieber JJ, Rothenberg M, Roman G, Feldmann KA, Ecker JR. CTR1, a negative regulator of the ethylene response pathway in Arabidopsis, encodes a member of the Raf family of protein kinases. Cell. 1993;72(3):427-441.

19. Guo H, Ecker JR. Plant responses to ethylene gas are mediated by SCE (EBEI/EBE2)-dependent proteolysis of EIN3 transcription factor. Cell. 2003;115:667-677.

20. An F, Zhao Q, Ji Y, Li W, Jiang Z, Yu X, Zhang C, Han Y, He W, Liu Y, Zhang S, Ecker JR, Guo H. Ethylene-induced stabilization of Ethylene Insensitive 3 and EIN3-LIKE1 is mediated by proteasomal degradation of EIN3 binding F-Box 1 and 2 that requires EIN2 in Arabidopsis. Plant Cell. 2010;22(7):2384-2401.

21. Pan Y, Seymour GB, Lu C, Hu ZI, Chen XQ, Chen GP. An ethylene response factor (ERF5) promoting adaptation to drought and salt tolerance in tomato. Plant Cell Rep. 2012;31(2):349-360. 
22. Binder BM, Rodriguez FI, Bleecker AB, Patterson SE. The effects of Group 11 transition metals, including gold, on ethylene binding to the ETR1 receptor and growth of Arabidopsis thaliana. FEBS LETT. 2007;581(26):5105-5109.

23. Qiao H, Chang KN, Yazaki J, Ecker JR. Interplay between ethylene, ETP1/ETP2 F-box proteins, and degradation of EIN2 triggers ethylene responses in Arabidopsis. Genes Dev. 2009;23(4):512-521.

24. Yanagisawa S, Yoo SD, Sheen J. Differential regulation of EIN3 stability by glucose and ethylene signalling in plants. Nature. 2003;425(6957):521-525.

25. Gibson SI, Laby RJ, Kim D. The sugar-insensitive1 (sis1) Mutant of Arabidopsis is allelic to ctr1. Biochem Bioph Res Co. 2001;280(1):196-203

26. Feng JX, Liu D, Pan Y, Gong W, Ma LG, Luo JC, Deng XW, Zhu YX. An annotation update via cDNA sequence analysis and comprehensive profiling of developmental, hormonal or environmental responsiveness of the Arabidopsis AP2/EREBP transcription factor gene family. Plant Mol Biol. 2005;59(6):853-868.

27. Mehrnia M, Balazadeh S, Zanor MI, Roeber BM. EBE, an AP2/ERF transcription factor highly expressed in proliferating cells, affects shoot architecture in Arabidopsis. Plant Physiol. 2013;162(2):842-857.

28. Nie J, Wen C, Xi L, Lv SH, Zhao QC, Kou YP, Ma N, Zhao LJ, Zhou XF. The AP2/ERF transcription factor CmERF053 of chrysanthemum positively regulates shoot branching, lateral root, and drought tolerance. Plant Cell Rep. 2018;37(7):1049-1060.

29. Mohamed Sathik MB, Luke LP, Rajamani A, Kuruvilla L, Sumesh KV, Thomas M. De novo transcriptome analysis of abiotic stressresponsive transcripts of Hevea brasiliensis. Mol Breeding. 2018;38(3):32.

30. Anderson JP, Kidd BN, Garg G, Singh KB. Transcriptome analysis reveals class IX ethylene response factors show specific upregulation in resistant but not susceptible Medicago truncatula lines following infection with Rhizoctonia solani. Eur $\mathrm{J}$ Plant Pathol. 2018;152(2):549-554.

31. Fortes AM, Teixeira RT, Agudelo-Romero P. Complex Interplay of Hormonal Signals during Grape Berry Ripening. Molecules. 2015;20(5):9326-9343.

32. Xu L, Yue Q, Xiang G, Bian F, Yao Y. Melatonin promotes ripening of grape berry via increasing the levels of $A B A, \mathrm{H}_{2} \mathrm{O}_{2}$, and particularly ethylene. Hortic Res. 2018;5(1):2-16.

33. Botondi R, Lodola L, Mencarelli F. Postharvest ethylene treatment affects berry dehydration, polyphenol and anthocyanin content by increasing the activity of cell wall enzymes in Aleatico wine grape. Eur Food Res Technol. 2011;232(4):679-685.

34. Eveland AL, Jackson DP. Sugars, signalling, and plant development. J Exp Bot. 2012;63(9):3367-3377.

35. Xin Zhao, Wen-Fang Li, Ying Wang, Zong-Huan Ma, Shi-Jin Yang, Qi Zhou, Juan Mao, Bai-Hong Chen. Elevated $\mathrm{CO}_{2}$ concentration promotes photosynthesis of grape (Vitis vinifera L. cv. 'Pinot noir') plantlet in vitro by regulating RbcS and Rca revealed by proteomic and transcriptomic profiles. BMC Plant Biol. 2019;19(1):42.

36. Ververidis P, John P. Complete recovery in vitro, of ethylene-forming enzyme activity. Phytochemistry. 1991;30(3):725-727.

37. Lin Z, Zhong S, Grierson D. Recent advances in ethylene research. J Exp Bot. 2009;60(12):3311-3336.

38. Xiao W, Sheen J, Jang JC. The role of hexokinase in plant sugar signal transduction and growth and development. Plant Mol Biol. 2000;44(4):451-461.

39. Vogel JP, Woeste KE, Kieber TJJ. Recessive and dominant mutations in the ethylene biosynthetic gene ACS5 of Arabidopsis confer cytokinin insensitivity and ethylene overproduction, respectively. P Natl Acad Sci USA. 1998;95(8):4766-4771.

40. Qu X, Hall BP, Gao Z, Schaller GE. A strong constitutive ethylene-response phenotype conferred on Arabidopsis plants containing null mutations in the ethylene receptors ETR1 and ERS1. BMC Plant Biol. 2007;7(3):1-15. 
41. Binder BM, Rodriguez FI, Bleecker AB. The Copper Transporter RAN1 Is Essential for Biogenesis of Ethylene Receptors in Arabidopsis. J Biol Chem. 2010;285(48):37263-37270.

42. Sun X, Zhao T, Gan S, Ren X, Fang L, Karungo SK, Wang Y, Chen L, Li S, Xin H. Ethylene positively regulates cold tolerance in grapevine by modulating the expression of Ethylene response factor 057. Sci Rep. 2016;6:24066.

43. Son GH, Wan J, Kim HJ, Nguyen XC, Chung WS, Hong JC, Stacey G. Ethylene-responsive element-binding factor 5, ERF5, is involved in chitin-induced innate immunity response. Mol Plant Microbe In. 2012;25(1):48-60.

44. Solano R, Stepanova A, Chao Q, Ecker JR. Nuclear events in ethylene signaling: a transcriptional cascade mediated by Ethyleneinsensitive3 and Ethylene-response-factor1. Genes \& Development. 1998;12(23):3703-3714.

45. Ohta M, Masaru Ohme-Takagi, Shinshi H. Three ethylene-responsive transcription factors in tobacco with distinct transactivation functions. Plant J. 2000;22(1):29-38.

46. Fujimoto SY, Ohta M, Usui A, Shinshi H, Ohme-Takagi M. Arabidopsis ethylene-responsive element binding factors act as transcriptional activators or repressors of GCC box-mediated gene expression. Plant Cell. 2000;12(3):393-404.

47. Sasaki K, Mitsuhara I, Seo S, Ito H, Matsui H, Ohashi Y. Two novel AP2/ERF domain proteins interact with cis-element VWRE for wound-induced expression of the Tobacco tpoxN1 gene. Plant J. 2010;50(6):1079-1092.

48. Bai Z, Li W, Jia Y, Yue Z, Jiao J, Huang W, Pengguo XP, Liang Z. The ethylene response factor SmERF6 co-regulates the transcription of SmCPS1 and SmKSL1 and is involved in tanshinone biosynthesis in Salvia miltiorrhiza hairy roots. Planta. 2018;248(1):243-255.

49. Fischer U, Drögelaser W. Overexpression of NtERF5, a new member of the tobacco ethylene response transcription factor family enhances resistance to tobacco mosaic virus. Mol Plant Microbe In. 2004;17(10):1162-1171.

50. Xiao YY, Chen JY, Kuang JF, Shan W, Xie H, Jiang Y.M, Lu WJ. Banana ethylene response factors are involved in fruit ripening through their interactions with ethylene biosynthesis genes. J Exp Bot. 2013;64(8):2499-2510.

51. Yang CY, Hsu FC, Li JP, Wang NN, Shih MC. The AP2/ERF transcription factor AtERF73/HRE1 modulates ethylene responses during hypoxia in Arabidopsis. Plant Physiol. 2011;156(1):202-212.

52. Yang Z, Tian L, Latoszek Green M, Brown D, Wu K. Arabidopsis ERF4 is a transcriptional repressor capable of modulating ethylene and abscisic acid responses. Plant Mol Biol. 2005;58(4):585-596.

53. Lee JM, Joung JG, McQuinn R, Chung MY, Fei ZJ, Tieman D, Klee H, Giovan noni J. Combined transcriptome, genetic diversity and metabolite profling in tomato fruit reveals that the ethylene response factor SIERF6 plays an im portant role in ripening and carotenoid accumulation. Plant J. 2012;70:191-204.

54. Li ZF, hang LX, Yu YW, Quan RD, Zhang ZJ, Zhang HW, Huang RF. The ethylene response factor AtERF11 that is transcriptionally modulated by the bZIP transcription factor HY5 is a crucial repressor for ethylene biosynthesis in Arabidopsis. Plant J. 2011;68(1):88-99.

55. Barratt DHP, Chrispeels MJ. Normal growth of Arabidopsis requires cytosolic invertase but not sucrose synthase. P Natl Acad Sci USA. 2009;106(31):13124.

56. Li T, Li Y, Wu QS. Exogenous carbon magnifies mycorrhizal effects on growth behaviour and sucrose metabolism in trifoliate orange. Not Bot Horti Agrobo. 2018;46(2):365-370.

57. Kosova AA, Khodyreva SN, Lavrik OI. Role of glyceraldehyde-3-phosphate dehydrogenase (GAPDH) in DNA repair. Biochemistry. 2017;82(6):643-654.

58. Crumbley C, Wang Y, Banerjee S, Burris TP. Regulation of expression of citrate synthase by the retinoic acid receptor-related orphan receptor a (RORa). PloS One. 2012;7(4):e33804.

59. Ahmed IM, Nadira UA, Bibi N, Cao F, He X, Zhang G, Wu F. Secondary metabolism and antioxidants are involved in the tolerance to drought and salinity, separately and combined, in Tibetan wild barley. Environ Exp Bot. 2015;111:1-12. 
60. Barreales D, Malheiro R, Pereira JA, Verdial J, Bento A, Casquero PA, Ribeiro AC. Effects of irrigation and collection period on grapevine leaf (Vitis vinifera L.var. Touriga Nacional): Evaluation of the phytochemical composition and antioxidant properties. $\mathrm{SCl}$ Hortic-Amsterdam. 2019;245:74-81.

61. Liu C, Zheng H, Sheng K, Liu W, Zheng L. Effects of postharvest UV-C irradiation on phenolic acids, flavonoids, and key phenylpropanoid pathway genes in tomato fruit. SCI Hortic-Amsterdam. 2018;241:107-114.

62. Jiang Y, Xia B, Liang L, Li X, Xu S, Peng F, Wang R. Molecular and analysis of a phenylalanine ammonia-lyase gene (LrPAL2) from Lycoris radiata. Mol Biol Rep. 2013;40(3):2293-2300.

63. Singh A, Selvi MT, Sharma R. Sun light-induced anthocyanin pigmentation in maize vegetative tissues. J Exp Bot. 1999;50(339):16191625.

64. Liu RR, Xu SH, Li JL, Hu YL, Lin ZP. Expression profile of a PAL gene from Astragalus membranaceus var. Mongholicus and its crucial role in flux into flavonoid biosynthesis. Plant Cell Rep. 2006;25(7):705-710.

65. Jiang YM, Xia N, Li XD, Shen WB, Liang LJ, Wang CY, Wang R, Peng F, Xia B. Molecular cloning and characterization of a phenylalanine ammonia-lyase gene (LrPAL) from Lycoris radiata. Mol Biol Rep. 2011;38(3):1935-1940.

66. Wen PF, Chen JY, Wan SB, Kong WF, Zhang P, Wang W, Zhan JC, Pan QH, Huang WD. Salicylic acid activates phenylalanine ammonialyase in grape berry in response to high temperature stress. Plant Growth Regul, 2008;55(1):1-10.

67. El-Awady AA, Mohamed SY, Abd El-Aziz MH, Aldrussi IA. Effect of sucrose and cold storage on senescence and anthocyanin accumulation in relation to gene expression of broccoli florets and sprout. Acta Hortic. 2017;1187:299-314.

68. Cui JD, Qiu JQ, Fan XW, Jia SR, Tan ZL. Biotechnological production and applications of microbial phenylalanine ammonia lyase: a recent review. Crit Rev Biotechnol. 2014;34(3):258.

69. Dubrovina AS, Kiselev KV. Regulation of stilbene biosynthesis in plants. Planta. 2017;246(4):597-623.

70. Yu O, Jez JM. Nature's assembly line: biosynthesis of simple phenylpropanoids and polyketides. Plant J. 2008;54(4):750-762.

71. Hara M, Oki K, Hoshino K, Kuboi T. Effects of sucrose on anthocyanin production in hypocotyl of two radish (Raphanus sativus) varieties. Plant Biotechnil-NAR. 2004;21(5):401-405.

72. Maclean DD, Murr DP, Deell JR, Mackay AB, Kupferman EM. Inhibition of PAL, CHS, and ERS1 Transcription by 1-MCP. Hortscience. 2007;45(1):46-55.

73. El-Kereamy A, Chervin C, Roustan JP, Moutounetb M, Raynala J, Fordc C, Latche A, Pecha JC, Bouzayen M. Exogenous ethylene stimulates the long-term expression of genes related to anthocyanin biosynthesis in grape berries. Physiol Plantarum. 2003;119(2):175182.

74. Patel RK, Mukesh J, Zhanjiang L. NGS QC Toolkit: A Toolkit for Quality Control of Next Generation Sequencing Data. PLoS ONE. 2012;7(2):e30619.

75. Kim D, Langmead B, Salzberg S. HISAT: a fast spliced aligner with low memory requirements. Nature Methods. 2015;12(4):357-360.

76. Smith PK, Krohn RI, Hermanson GT, Mallia AK, Gartner FH, Provenzano MD, Fujimoto EK, Goeke NM, Olson BJ, Klenk DC. Measurement of protein using bicinchoninic acid. Anal Biochem. 1985;150(1):76-85.

77. Wu X, Xiong E, Wang W, Scali M, Cresti M. Universal sample preparation method integrating trichloroacetic acid/acetone precipitation with phenol extraction for crop proteomic analysis. Nat Protoc. 2014;9(2): 362-374.

78. Joseph M. Proteomic characterisation of endoplasmic reticulum-derived protein bodies in tobacco leaves. BMC Plant Biol. 2012;12:36.

\section{Tables}

Page $12 / 23$ 
Table 1: Phenotypical characteristics changes of 'Pinot Noir' plantlet in vitro

\begin{tabular}{cllllll} 
& $\begin{array}{l}\text { Fresh weight of } \\
\text { aerial parts }(\mathrm{g})\end{array}$ & $\begin{array}{l}\text { Fresh weight of } \\
\text { underground part }(\mathrm{g})\end{array}$ & $\begin{array}{l}\text { Dry weight of } \\
\text { aerial parts }(\mathrm{g})\end{array}$ & $\begin{array}{l}\text { Dry weight of } \\
\text { underground part }(\mathrm{g})\end{array}$ & $\begin{array}{l}\text { leaf } \\
\text { area(cm2) }\end{array}$ & $\begin{array}{l}\text { plantlet } \\
\text { height } \\
(\mathrm{cm})\end{array}$ \\
\hline CK & $0.56 \pm 0.02 \mathrm{c}$ & $0.07 \pm 0.04 \mathrm{c}$ & $0.04 \pm 0.02 \mathrm{~b}$ & $0.01 \pm 0.003 \mathrm{a}$ & $2.98 \pm 0.04 \mathrm{c}$ & $4.63 \pm 0.04 \mathrm{c}$ \\
\hline S1 & $0.60 \pm 0.03 \mathrm{c}$ & $0.59 \pm 0.06 \mathrm{a}$ & $0.05 \pm 0.03 \mathrm{~b}$ & $0.03 \pm 0.016 \mathrm{a}$ & $4.07 \pm 0.07 \mathrm{~b}$ & $5.78 \pm 0.33 \mathrm{~b}$ \\
\hline C0 & $0.82 \pm 0.07 \mathrm{~b}$ & $0.27 \pm 0.03 \mathrm{~b}$ & $0.07 \pm 0.02 \mathrm{~b}$ & $0.01 \pm 0.004 \mathrm{a}$ & $6.67 \pm 0.04 \mathrm{a}$ & $6.29 \pm 0.19 \mathrm{~b}$ \\
\hline Cs & $1.02 \pm 0.04 \mathrm{a}$ & $0.50 \pm 0.04 \mathrm{a}$ & $0.16 \pm 0.03 \mathrm{a}$ & $0.02 \pm 0.005 \mathrm{a}$ & $7.97 \pm 0.06 \mathrm{a}$ & $7.56 \pm 0.08 \mathrm{a}$
\end{tabular}

Table 2: The accession and molecular function of DEGs from exogenous carbon treatments compared with CK 


\begin{tabular}{|c|c|c|c|c|}
\hline Gene ID & Gene name & Molecular Function & Sub-classifications & Categories \\
\hline CTR7 & $C T r 7$ & $\begin{array}{l}\text { Copper ion transmembrane } \\
\text { transporter activity }\end{array}$ & metal ion & Transport \\
\hline LOC100233051 & MT & metal ion binding & metal ion & Transport \\
\hline LOC100242429 & NUDIX 18 & $\begin{array}{l}\text { Hydrolase activity, acting on acid } \\
\text { anhydrides, in phosphorus- } \\
\text { containing anhydrides }\end{array}$ & nucleoside & Primary metabolism \\
\hline LOC100242506 & $\begin{array}{l}\text { Glutathione S- } \\
\text { transferase } \\
\text { F13 }\end{array}$ & Glutathione transferase activity & glutathione metabolic & Secondary metabolism \\
\hline LOC100243221 & $A B C C 10$ & $\begin{array}{l}\text { ATPase activity, coupled to } \\
\text { transmembrane movement of } \\
\text { substances/ATP binding }\end{array}$ & $\begin{array}{l}\text { energy(transmembrane } \\
\text { transport) }\end{array}$ & Transport \\
\hline LOC100243852 & $\mathrm{F} 3 \mathrm{H}$ & $\begin{array}{l}\text { Oxidoreductase activity/ metal ion } \\
\text { binding }\end{array}$ & flavonoid biosynthetic & Secondary metabolism \\
\hline LOC100243915 & $n s-L T P 2$ & Lipid binding & lipid transport & Transport \\
\hline LOC100244286 & beta-glu 13 & $\begin{array}{l}\text { Vicianin beta-glucosidase } \\
\text { activity/hydrolase activity, } \\
\text { hydrolyzing O-glycosyl compounds }\end{array}$ & $\begin{array}{l}\text { carbohydrate catabolic } \\
\text { process }\end{array}$ & Primary metabolism \\
\hline LOC100244353 & ERF5 & $\begin{array}{l}\text { DNA binding/DNA-binding } \\
\text { transcription factor activity }\end{array}$ & DNA repair & Transcription \\
\hline LOC100244913 & & - & - & Uncharacterized \\
\hline LOC100245930 & $n s-L T P 8$ & Lipid binding & lipid transport & Transport \\
\hline LOC100247598 & beta-glu 12 & Beta-glucosidase activity & $\begin{array}{l}\text { carbohydrate } \\
\text { metabolic process }\end{array}$ & Primary metabolism \\
\hline LOC100247763 & ERF5 & $\begin{array}{l}\text { DNA binding/DNA-binding } \\
\text { transcription factor activity }\end{array}$ & $\begin{array}{l}\text { DNA-binding } \\
\text { transcription factor } \\
\text { activity }\end{array}$ & Transcription \\
\hline LOC100249012 & & - & - & Uncharacterized \\
\hline LOC100249271 & CaBP CML45 & Calcium ion binding & metal ion & Transport \\
\hline LOC100249367 & CYP $714 C 2$ & $\begin{array}{l}\text { Heme binding/monooxygenase } \\
\text { activity/iron ion } \\
\text { binding/oxidoreductase activity, } \\
\text { acting on paired donors, with } \\
\text { incorporation or reduction of } \\
\text { molecular oxygen }\end{array}$ & - & Secondary metabolism \\
\hline LOC100249507 & ERF105 & $\begin{array}{l}\text { Transcription factor activity, } \\
\text { sequence-specific DNA binding }\end{array}$ & $\begin{array}{l}\text { DNA-binding } \\
\text { transcription factor } \\
\text { activity }\end{array}$ & Transcription \\
\hline LOC100250788 & CYP 706C & $\begin{array}{l}\text { Flavonoid 3'-monooxygenase } \\
\text { activity/heme binding/iron ion } \\
\text { binding }\end{array}$ & flavonoid biosynthetic & Secondary metabolism \\
\hline LOC100252971 & $\begin{array}{l}\text { 1,3- } \beta \text { - } \\
\text { glucanase }\end{array}$ & $\begin{array}{l}\text { Hydrolase activity, hydrolyzing O- } \\
\text { glycosyl compounds/polysaccharide } \\
\text { binding }\end{array}$ & $\begin{array}{l}\text { carbohydrate } \\
\text { metabolic process }\end{array}$ & Primary metabolism \\
\hline LOC100253211 & SCPL7 & $\begin{array}{l}\text { Transferase activity, transferring acyl } \\
\text { groups other than amino-acyl groups }\end{array}$ & proteolysis & Secondary metabolism \\
\hline LOC100253381 & ATL2 & Ubiquitin protein ligase activity & protein ubiquitination & Translation/protein \\
\hline LOC100253485 & CAF1 & $\begin{array}{l}\text { Nucleic acid binding/poly(A)-specific } \\
\text { ribonuclease activity }\end{array}$ & RNA biosynthesis & $\begin{array}{l}\text { Transcription/polynucleotide } \\
\text { Biosynthesis }\end{array}$ \\
\hline LOC100253692 & $P E$ & $\begin{array}{l}\text { Aspartyl esterase } \\
\text { activity/pectinesterase }\end{array}$ & growth & Cell morphogenesis \\
\hline
\end{tabular}


activity/pectinesterase inhibitor activity

\begin{tabular}{|c|c|c|c|c|}
\hline LOC100254616 & ERF5 & $\begin{array}{l}\text { Transcription factor activity, } \\
\text { sequence-specific DNA binding }\end{array}$ & $\begin{array}{l}\text { DNA-binding } \\
\text { transcription factor } \\
\text { activity }\end{array}$ & Transcription \\
\hline LOC100254640 & ERF2 & $\begin{array}{l}\text { DNA binding/DNA-binding } \\
\text { transcription factor activity }\end{array}$ & $\begin{array}{l}\text { DNA-binding } \\
\text { transcription factor } \\
\text { activity }\end{array}$ & Transcription \\
\hline LOC100254909 & TYDC1 & $\begin{array}{l}\text { Aromatic-L-amino-acid } \\
\text { decarboxylase activity/tyrosine } \\
\text { decarboxylase activity/pyridoxal } \\
\text { phosphate binding }\end{array}$ & amino acid metabolic & Primary metabolism \\
\hline LOC100255006 & SCPL45 & $\begin{array}{l}\text { Carboxypeptidase } \\
\text { activity/transferase activity, } \\
\text { transferring acyl groups other than } \\
\text { amino-acyl groups }\end{array}$ & protein modification & Translation/protein \\
\hline LOC100255112 & $P O D$ & $\begin{array}{l}\text { heme binding/peroxidase } \\
\text { activity/metal ion binding }\end{array}$ & oxidative stress & Stress tolerance \\
\hline LOC100255176 & SAUR4O & - & hormone & Bio-signaling \\
\hline LOC100255226 & HSPRO2 & Heme binding/metal ion binding & biotic stress & Stress tolerance \\
\hline LOC100255246 & OEP16 & $\begin{array}{l}\text { Protein import into chloroplast } \\
\text { stroma/protein import into } \\
\text { mitochondrial matrix }\end{array}$ & protein & Transport \\
\hline LOC100255547 & OsXTH & $\begin{array}{l}\text { Hydrolase activity, hydrolyzing 0- } \\
\text { glycosyl } \\
\text { compounds/xyloglucan:xyloglucosyl } \\
\text { transferase activity }\end{array}$ & growth & Cell morphogenesis \\
\hline LOC100255800 & $D T X 41$ & $\begin{array}{l}\text { Drug transmembrane transporter } \\
\text { activity/solute:proton antiporter } \\
\text { activity }\end{array}$ & metabism transporter & Transport \\
\hline LOC100255939 & $P A L$ & $\begin{array}{l}\text { Phenylalanine ammonia-lyase } \\
\text { activity }\end{array}$ & flavonoid biosynthetic & Secondary metabolism \\
\hline LOC100257047 & & - & - & Uncharacterized \\
\hline LOC100257500 & GA 20-oxidase & $\begin{array}{l}\text { Gibberellin 20-oxidase activity/metal } \\
\text { ion binding }\end{array}$ & hormone & Bio-signaling \\
\hline LOC100257695 & PEAMT & $\begin{array}{l}\text { Phosphoethanolamine } \mathrm{N} \text { - } \\
\text { methyltransferase activity/S- } \\
\text { adenosylmethionine-dependent } \\
\text { methyltransferase activity }\end{array}$ & protein modification & Translation/protein \\
\hline LOC100258846 & 6-OMT & $\begin{array}{l}\text { O-methyltransferase activity/protein } \\
\text { dimerization activity/S- } \\
\text { adenosylmethionine-dependent } \\
\text { methyltransferase activity }\end{array}$ & protein modification & Translation/protein \\
\hline LOC100259725 & ERF105 & $\begin{array}{l}\text { DNA binding/DNA-binding } \\
\text { transcription factor activity }\end{array}$ & $\begin{array}{l}\text { DNA-binding } \\
\text { transcription factor } \\
\text { activity }\end{array}$ & Transcription \\
\hline LOC100260258 & & Metal ion binding & - & Uncharacterized \\
\hline LOC100260626 & AGP31 & - & growth & Cell morphogenesis \\
\hline LOC100261260 & ERF5 & $\begin{array}{l}\text { DNA binding/DNA-binding } \\
\text { transcription factor activity }\end{array}$ & $\begin{array}{l}\text { DNA-binding } \\
\text { transcription factor } \\
\text { activity }\end{array}$ & Transcription \\
\hline LOC100262206 & HSPs & - & abiotic stress & Stress tolerance \\
\hline LOC100263433 & MUR3 & $\begin{array}{l}\text { Transferase activity, transferring } \\
\text { glycosyl groups }\end{array}$ & $\begin{array}{l}\text { carbohydrate } \\
\text { metabolic process }\end{array}$ & Primary metabolism \\
\hline LOC100264526 & bHLH93 & Transcription factor activity, & DNA-binding & Transcription \\
\hline
\end{tabular}


sequence-specific DNA binding/DNA binding/

\begin{tabular}{|c|c|c|c|c|}
\hline LOC100265220 & SCPL 16 & $\begin{array}{l}\text { Transferase activity, transferring acyl } \\
\text { groups other than amino-acyl groups }\end{array}$ & proteolysis & Secondary metabolism \\
\hline LOC100265720 & bHLH51 & $\begin{array}{l}\text { Transcription factor activity, } \\
\text { sequence-specific DNA binding/DNA } \\
\text { binding }\end{array}$ & $\begin{array}{l}\text { DNA-binding } \\
\text { transcription factor } \\
\text { activity }\end{array}$ & Transcription \\
\hline LOC100265969 & $4 C L 5$ & Catalytic activity & protein modification & Translation/protein \\
\hline LOC100266479 & $\begin{array}{l}\text { GDSL } \\
\text { esterase/lipase }\end{array}$ & $\begin{array}{l}\text { Hydrolase activity, acting on ester } \\
\text { bonds }\end{array}$ & lipid & Primary metabolism \\
\hline LOC100267224 & & - & - & Uncharacterized \\
\hline LOC100267366 & & - & - & Uncharacterized \\
\hline LOC100267812 & & - & - & Uncharacterized \\
\hline LOC100852581 & & - & - & Uncharacterized \\
\hline LOC100852631 & $3 G T$ & $\begin{array}{l}\text { Flavonol 3-0-glucosyltransferase } \\
\text { activity/daphnetin 3-0- } \\
\text { glucosyltransferase } \\
\text { activity/myricetin 3-0- } \\
\text { glucosyltransferase activity }\end{array}$ & flavonoid biosynthetic & Secondary metabolism \\
\hline LOC100852930 & & - & - & Uncharacterized \\
\hline LOC100852969 & $B N M 2 A$ & Seed development & growth & Cell morphogenesis \\
\hline LOC100853024 & $S 2$ & - & differentiation & Cell morphogenesis \\
\hline LOC100853060 & P4 & - & differentiation & Cell morphogenesis \\
\hline LOC100854364 & SBT5.3 & Serine-type endopeptidase activity & protein modification & Translation/protein \\
\hline LOC100854550 & RHG1A & $\begin{array}{l}\text { Ubiquitin protein ligase activity/zinc } \\
\text { ion binding }\end{array}$ & protein modification & Translation/protein \\
\hline LOC100854991 & & - & - & Uncharacterized \\
\hline LOC100855013 & & - & - & Uncharacterized \\
\hline LOC104881847 & & - & - & Uncharacterized \\
\hline LOC109121674 & $G T$ & $\begin{array}{l}\text { Quercetin 3-0-glucosyltransferase } \\
\text { activity/quercetin 7-0- } \\
\text { glucosyltransferase activity }\end{array}$ & - & Secondary metabolism \\
\hline LOC109122826 & $G S T$ & Glutathione transferase activity & - & Secondary metabolism \\
\hline LOC100257217 & $D 14$ & Hydrolase activity & lipid & Primary metabolism \\
\hline LOC100260805 & CaBP CML37 & $\begin{array}{l}\text { Calcium:sodium antiporter } \\
\text { activity/calcium ion binding }\end{array}$ & metal ion & Transport \\
\hline LOC100266388 & CYP 82D47 & - & - & Secondary metabolism \\
\hline LOC100266419 & $D 14$ & - & lipid & Primary metabolism \\
\hline SODCP & SODCP & $\begin{array}{l}\text { Metal ion binding/superoxide } \\
\text { dismutase activity }\end{array}$ & abiotic stress & Stress tolerance \\
\hline
\end{tabular}

Table 3: The accession and molecular function of DEPs from exogenous carbon treatment compared with CK

transcription factor activity

\section{DNA-binding}

transcription factor activity

protein modification Translation/protein

Hydrolase activity, acting on ester lipid

Uncharacterized sequence-specific DNA binding/DNA

Uncharacterized

Flavonol 3-0-glucosyltransferase activity/daphnetin 3-0 (t) glucosyltransferase activity 


\begin{tabular}{|c|c|c|c|c|}
\hline $\begin{array}{l}\text { Protein } \\
\text { Accession }\end{array}$ & Protein name & Molecular Function & Sub-classifications & Categories \\
\hline NP_001267871.1 & $\begin{array}{l}\text { ACC oxidase } \\
2\end{array}$ & Metal ion binding/oxidoreductase activity & $\begin{array}{l}\text { ethylene } \\
\text { biosynthetic } \\
\text { process }\end{array}$ & Bio-signaling \\
\hline NP_001267891.1 & Chitinase & Chitinase activity/chitin binding & $\begin{array}{l}\text { carbohydrate } \\
\text { metabolic process }\end{array}$ & $\begin{array}{l}\text { Primary } \\
\text { metabolism }\end{array}$ \\
\hline NP_001267896.1 & GluB & $\begin{array}{l}\text { Hydrolase activity, hydrolyzing O-glycosyl } \\
\text { compounds/polysaccharide binding }\end{array}$ & $\begin{array}{l}\text { carbohydrate } \\
\text { metabolic process }\end{array}$ & $\begin{array}{l}\text { Primary } \\
\text { metabolism }\end{array}$ \\
\hline NP_001267956.1 & PR10.3 & - & defense response & Stress tolerance \\
\hline NP_001268064.1 & $\mathrm{CHS}$ & $\begin{array}{l}\text { Transferase activity, transferring acyl groups other } \\
\text { than amino-acyl groups }\end{array}$ & $\begin{array}{l}\text { biosynthetic } \\
\text { process }\end{array}$ & $\begin{array}{l}\text { Secondary } \\
\text { metabolism }\end{array}$ \\
\hline NP_001268098.1 & GCat & Catalase activity/heme binding/metal ion binding & oxidative stress & Stress tolerance \\
\hline NP_001268120.1 & LTP & Lipid binding & lipid transport & Transport \\
\hline NP_001268153.1 & GluB & $\begin{array}{l}\text { Hydrolase activity, hydrolyzing 0-glycosyl } \\
\text { compounds }\end{array}$ & $\begin{array}{l}\text { carbohydrate } \\
\text { metabolic process }\end{array}$ & $\begin{array}{l}\text { Primary } \\
\text { metabolism }\end{array}$ \\
\hline XP_002262842.1 & GST & Glutathione ransferase activity & $\begin{array}{l}\text { glutathione } \\
\text { metabolic process }\end{array}$ & Stress tolerance \\
\hline XP_002263986.1 & SYP121 & SNAP receptor activity/SNARE binding & - & Transport \\
\hline XP_002269677.1 & CSLA2 & $\begin{array}{l}\text { Glucomannan 4-beta-mannosyltransferase } \\
\text { activity/mannan synthase activity }\end{array}$ & - & $\begin{array}{l}\text { Secondary } \\
\text { metabolism }\end{array}$ \\
\hline XP_002269908.1 & & Hydrolase activity & - & Uncharacterized \\
\hline XP_002269918.1 & POD4 & Heme binding/metal ion binding/peroxidase activity & oxidative stress & Stress tolerance \\
\hline XP_002270155.1 & & Nutrient reservoir activity & - & Uncharacterized \\
\hline XP_002270970.1 & nsLTP & Lipid binding & lipid transport & Transport \\
\hline XP_002271896.1 & SUS & Sucrose synthase activity & $\begin{array}{l}\text { sucrose metabolic } \\
\text { process }\end{array}$ & $\begin{array}{l}\text { Primary } \\
\text { metabolism }\end{array}$ \\
\hline XP_002274242.1 & PR10.2 & - & defense response & Stress tolerance \\
\hline XP_002274535.1 & PR10.2 & - & defense response & Stress tolerance \\
\hline XP_002275501.1 & & Hydrolase activity & - & Uncharacterized \\
\hline XP_002276351.1 & $\begin{array}{l}\text { beta-D- } \\
\text { xylosidase } \mathrm{X} 1\end{array}$ & $\begin{array}{l}\text { Hydrolase activity, hydrolyzing 0-glycosyl } \\
\text { compounds }\end{array}$ & $\begin{array}{l}\text { carbohydrate } \\
\text { metabolic process }\end{array}$ & $\begin{array}{l}\text { Primary } \\
\text { metabolism }\end{array}$ \\
\hline XP_002276353.1 & $4 \mathrm{CL} 7$ & Fatty-acyl-CoA synthase activity & - & Bio-signaling \\
\hline XP_002276431.1 & & - & - & Uncharacterized \\
\hline XP_002276777.1 & BAM9 & $\begin{array}{l}\text { Amylopectin maltohydrolase activity/beta-amylase } \\
\text { activity }\end{array}$ & $\begin{array}{l}\text { carbohydrate } \\
\text { metabolic process }\end{array}$ & $\begin{array}{l}\text { Primary } \\
\text { metabolism }\end{array}$ \\
\hline XP_002276965.1 & KPHMT & $\begin{array}{l}\text { 3-methyl-2-oxobutanoate hydroxymethyltransferase } \\
\text { activity }\end{array}$ & $\begin{array}{l}\text { pantothenate } \\
\text { biosynthetic } \\
\text { process }\end{array}$ & Energy \\
\hline XP_002278007.1 & 9S-LOX5 & $\begin{array}{l}\text { Metal ion bindingoxidoreductase activity, acting on } \\
\text { single donors with incorporation of molecular } \\
\text { oxygen, incorporation of two atoms of oxygen }\end{array}$ & $\begin{array}{l}\text { oxylipin } \\
\text { biosynthetic proces }\end{array}$ & Translation \\
\hline XP_002278138.1 & $\mathrm{ACO} 2$ & - & $\begin{array}{l}\text { tricarboxylic acid } \\
\text { cycle }\end{array}$ & $\begin{array}{l}\text { Primary } \\
\text { metabolism }\end{array}$ \\
\hline XP_002278339.1 & GGP2 & GDP-D-glucose phosphorylase activity & $\begin{array}{l}\text { glucose metabolic } \\
\text { process }\end{array}$ & Stress tolerance \\
\hline XP_002278643.1 & & - & - & Uncharacterized \\
\hline
\end{tabular}


XP_002280106.1 SAM

synthetase 5
ATP binding/metal ion binding/methionine adenosyltransferase activity
Sadenosylmethionine biosynthetic process

XP_002280532.1 GST Glutathione transferase activity

XP_002281607.1 PHOS32

XP_002281799.1 PAL

XP_002282132.1 betagalactosidase

XP_002282836.1

XP_002282917.2 P21

XP_002283030.1 P21

XP_002283150.1

XP_002283780.1 AOS1

XP_002284064.1 CS

XP_002284278.1 POD73

XP_002285653.1 KAT2

XP_002285723.1 CPOD

XP_010651402.1 NRX

XP_010656112.1 ALDH7

XP_010658590.1 UXS

XP_010660502.1 AOC

XP_002270414.1 GAPDH

XP_003635074.1 LHCP

XP_002272549.1

XP_002277520.2

XP_002278812.3

XP_002280729.1

XP_002282477.2

XP_002284136.1

XP_002284571.1

XP_002284864.1

XP_003633883.1

XP_010644121.1

\section{$-$}

Phenylalanine ammonia-lyase activity

Beta-galactosidase activity/carbohydrate binding

Transferase activity, transferring acyl groups other than amino-acyl groups

-
-
-
Heme binding/iron ion binding/monooxygenase
activity/oxidoreductase activity, acting on paired
donors, with incorporation or reduction of molecular
oxygen

Transferase activity, transferring acyl groups, acyl groups converted into alkyl on transfer

Heme binding/metal ion binding/peroxidase activity

Transferase activity, transferring acyl groups other than amino-acyl groups

Heme binding/metal ion binding/peroxidase activity

Thioredoxin-disulfide reductase activity

Oxidoreductase activity, acting on the aldehyde or oxo group of donors, NAD or NADP as acceptor

NAD+ binding/UDP-glucuronate decarboxylase activity

allene-oxide cyclase activity
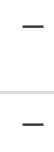

-

$-$

-

-

-

-

- glutathione

metabolic process

-

phenylpropanoid metabolic process

carbohydrate metabolic process

$-$

$-$

$-$

$-$

defense response/

\section{tricarboxylic acid} cycle

defense response/

$-$

defense response/

oxidative stress

oxidative stress

$-$

$-$

jasmonic acid biosynthetic process

\begin{tabular}{ll}
$\begin{array}{l}\text { sucrose metabolic } \\
\text { process }\end{array}$ & $\begin{array}{l}\text { Primary } \\
\text { metabolism }\end{array}$ \\
\hline $\begin{array}{l}\text { carbohydrate } \\
\text { metabolic process }\end{array}$ & $\begin{array}{l}\text { Primary } \\
\text { metabolism }\end{array}$ \\
- & Uncharacterized \\
- & Uncharacterized \\
- & Uncharacterized \\
- & Uncharacterized \\
- & Uncharacterized \\
- & Uncharacterized \\
- & Uncharacterized \\
- & Uncharacterized \\
- & Uncharacterized \\
- & Uncharacterized
\end{tabular}

Primary metabolism

Stress tolerance

Translation

Stress tolerance

Stress tolerance

Stress tolerance

Primary metabolism

Bio-signaling 


\begin{tabular}{|c|c|c|c|}
\hline XP_010648868.2 & - & - & Uncharacterized \\
\hline XP_010654144.1 & - & - & Uncharacterized \\
\hline XP_010654522.1 & - & - & Uncharacterized \\
\hline XP_010658505.1 & - & - & Uncharacterized \\
\hline XP_019075863.1 & - & - & Uncharacterized \\
\hline XP_019077167.1 & - & - & Uncharacterized \\
\hline XP_019082045.1 & - & - & Uncharacterized \\
\hline
\end{tabular}

Table 4: Ethylene metabolism-related genes and proteins that differentially expressed at exogenous carbon versus CK.

\begin{tabular}{|c|c|c|c|c|c|c|c|c|c|}
\hline \multirow[t]{3}{*}{ Gene } & \multirow[t]{3}{*}{ Protein } & \multirow{3}{*}{$\begin{array}{l}\text { Transcripts } \\
\text { Identified }\end{array}$} & \multirow{3}{*}{$\begin{array}{l}\text { Proteomics } \\
\text { Identified }\end{array}$} & \multirow{2}{*}{\multicolumn{3}{|c|}{$\begin{array}{l}\text { FPKM } \\
\text { Fold } \\
\text { Change }\end{array}$}} & \multirow{2}{*}{$\begin{array}{l}\text { Relative } \\
\text { expression } \\
\text { level }\end{array}$} & \multirow[b]{3}{*}{ CO/CK } & \multirow[b]{3}{*}{ S1/CK } \\
\hline & & & & & & & & & \\
\hline & & & & $\mathrm{Cs} / \mathrm{CK}$ & $\mathrm{CO} / \mathrm{CK}$ & S1/CK & $\mathrm{Cs} / \mathrm{CK}$ & & \\
\hline METK5 & $\begin{array}{l}\text { SAM } \\
\text { synthase } \\
5\end{array}$ & $\sqrt{ }$ & $\sqrt{ }$ & $1.30 / 1.46 *$ & $1.19 / 1.525^{\star}$ & $0.85 / 1.25^{\star}$ & 2.63 & 2.75 & 2.38 \\
\hline ACO2 & $\begin{array}{l}\text { ACC } \\
\text { oxidase } 2\end{array}$ & $\sqrt{ }$ & $\sqrt{ }$ & $0.86 / 0.64^{*}$ & $1.51 / 0.67 *$ & $0.93 / 0.64^{\star}$ & 0.95 & 4.60 & 3.73 \\
\hline CTR7 & CTR7 & $\sqrt{ }$ & & 5.25 & 2.52 & 0.23 & 3.53 & 3.49 & 0.71 \\
\hline ERF5 & ERF5 & $\sqrt{ }$ & & 4.85 & 4.91 & 3.76 & 4.44 & 4.24 & 3.17 \\
\hline ERF5 & ERF5 & $\sqrt{ }$ & & 3.91 & 3.59 & 2.91 & 2.10 & 4.02 & 1.71 \\
\hline ERF105 & ERF105 & $\sqrt{ }$ & & 4.28 & 3.28 & 3.10 & 3.59 & 2.40 & 2.93 \\
\hline ERF5 & ERF5 & $\sqrt{ }$ & & 4.12 & 3.01 & 3.66 & 1.50 & 5.46 & 3.58 \\
\hline ERF2 & ERF2 & $\sqrt{ }$ & & 2.93 & 2.43 & 2.22 & 3.82 & 5.84 & 2.36 \\
\hline ERF105 & ERF105 & $\sqrt{ }$ & & 2.46 & 2.40 & 2.21 & 1.54 & 2.54 & 1.26 \\
\hline ERF5 & ERF5 & $\sqrt{ }$ & & 3.44 & 2.35 & 2.51 & 3.81 & 5.25 & 1.57 \\
\hline
\end{tabular}

* The relative protein Fold Change.

\section{Figures}




\section{CK}

\section{S1}

C0

Cs
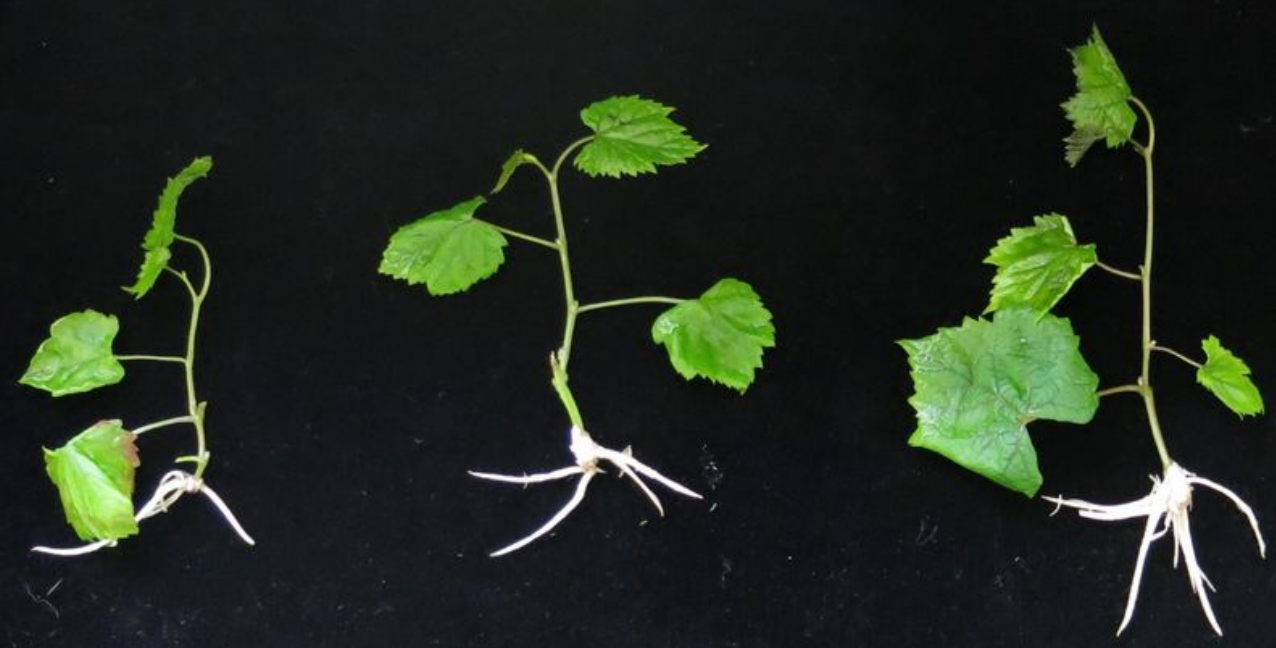

$\overline{\mathrm{cm}}$

Figure 1

Effects of exogenous carbon on phenotypes of grape plantlets in vitro. The leaf area, plantlet height and shoot increased significantly in exogenous carbon treatment compared with CK.

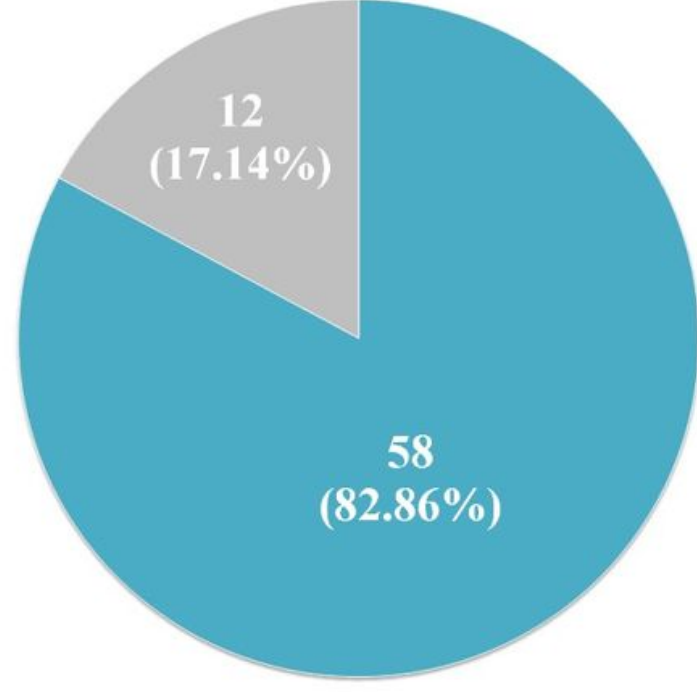

- Characterized

- Uncharacterized

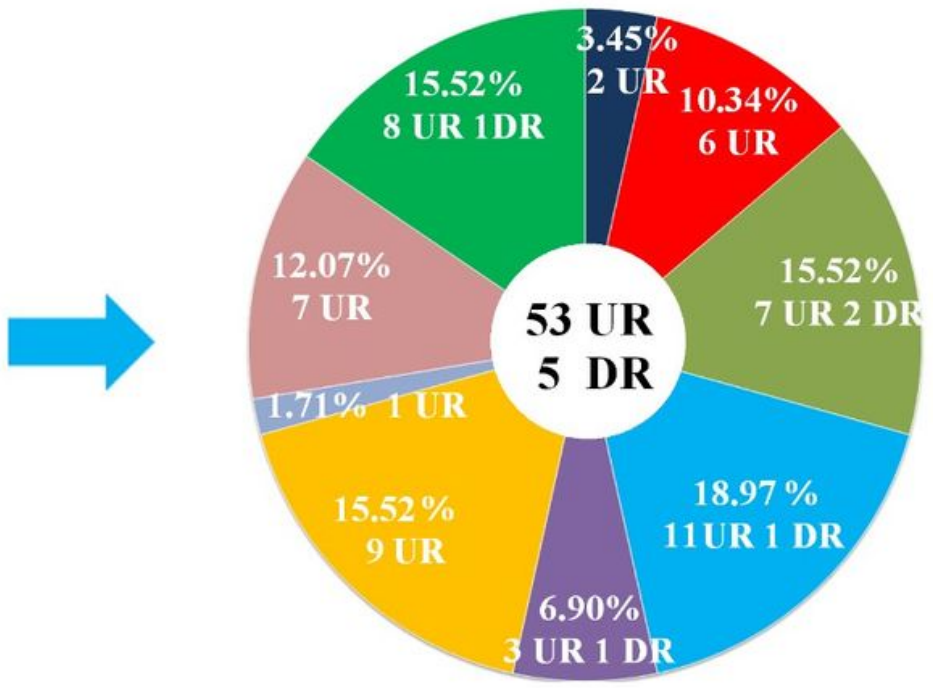

- Bio-signaling

- Cell morphogenesis

- Primary metabolism

- Secondary metabolism

- Stress tolerance

- Transcription

Translation/protein

- Transport

- Transcription/polynucleotide biosynthesis

Figure 2 
Distribution and classification of differentially expressed genes (DEGs) at Cs, C0 and S1 compared with CK. UR and DR representing upregulation and down-regulation, respectively.

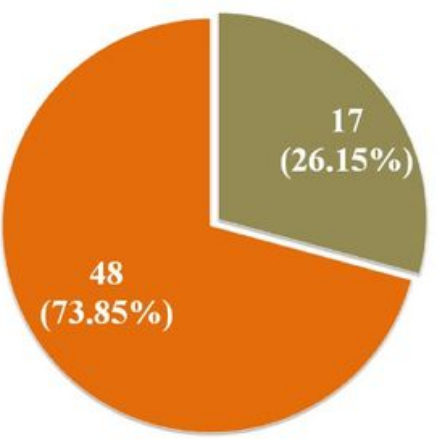

Uncharacterized proteins

Characterized proteins

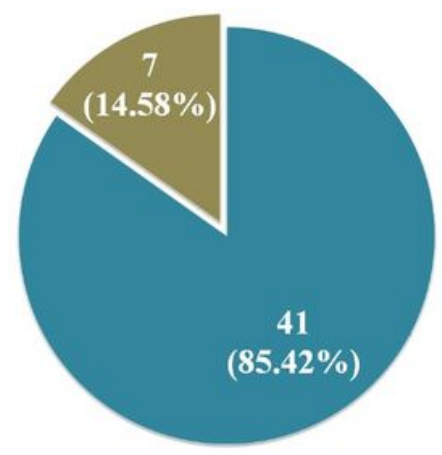

Uncharacterized proteins

Characterized proteins

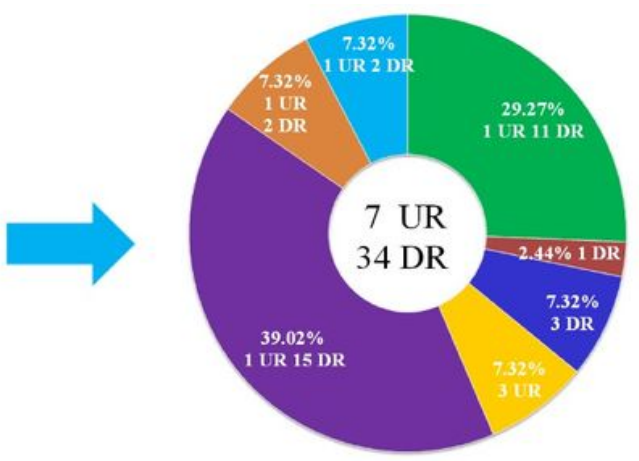

Energy $\quad$ Primary metabolism

- Bio-signaling $\quad$ Translation

- Transport $\quad$ Stress tolerance

Secondary metabolism

Figure 3

Distribution and classification of differentially expressed protein (DEPs) at Cs, C0 and S1 compared with CK.

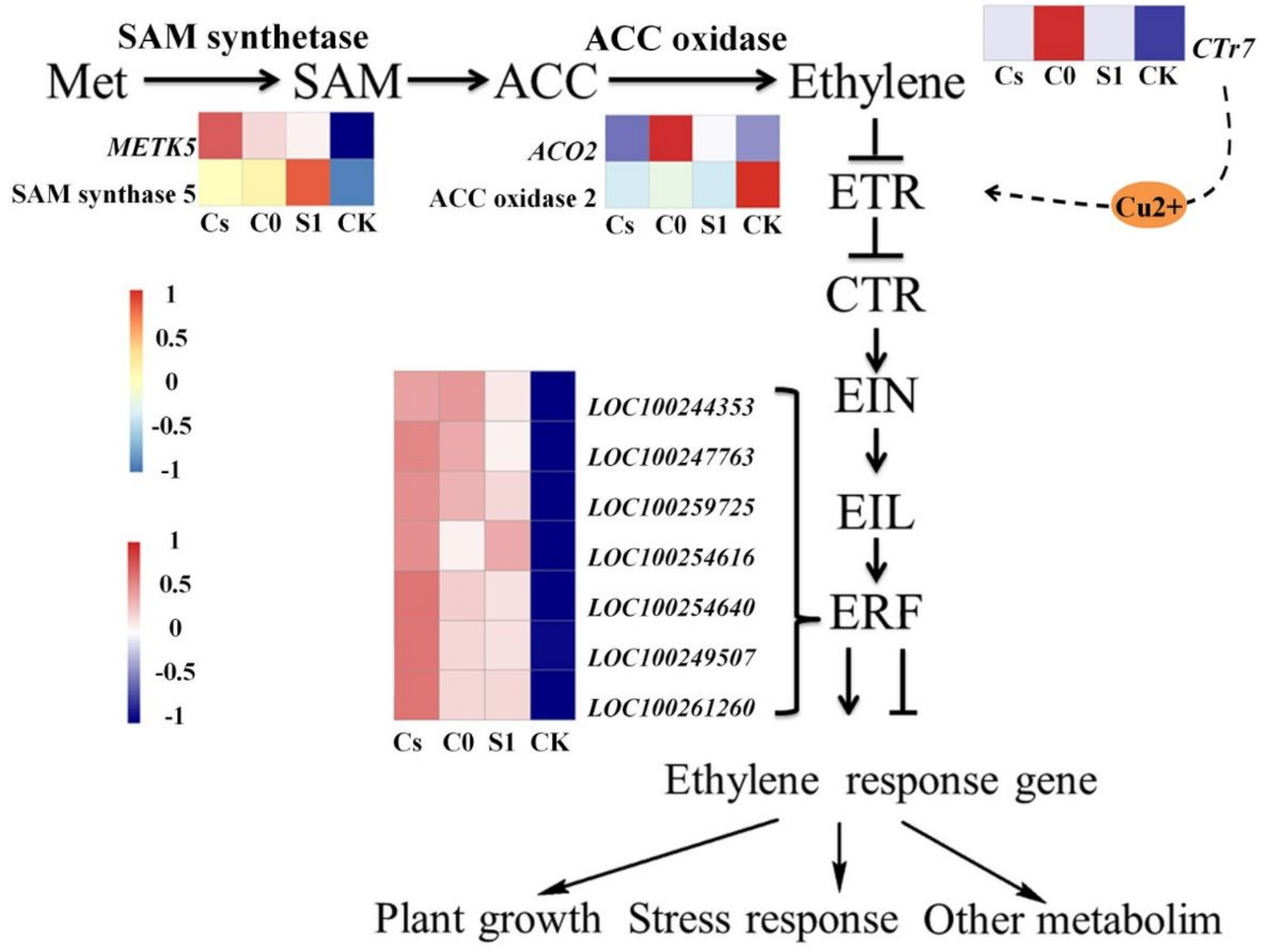

Figure 4 
Ethylene metabolism pathway with up-regulated genes and proteins at exogenous carbon versus CK shown in red. The changing DEGs include 7 of ERFs and 1 CTR. The changing DEPs include S-adenosylmethionine synthase 5 (SAM synthase) and 1-aminocyclopropane1-carboxylic acid oxidase 2 (ACC oxidase 2).
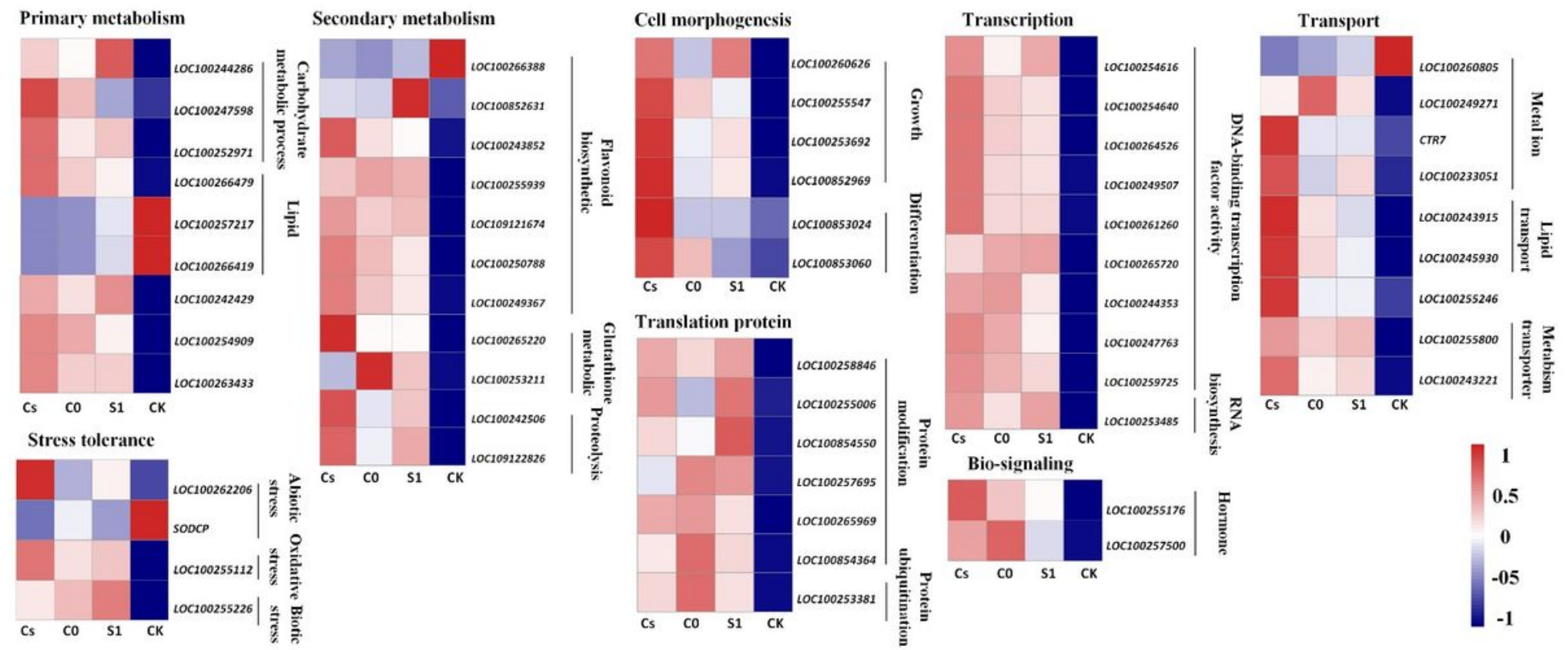

Figure 5

Gene expression heat map shows differential regulation at Cs, C0 and S1 compared with CK based on fragments per kb per million reads (FPKM). Differentially expressed genes have been categorized into primary metabolism; secondary metabolism; cell morphogenesis; biosignaling; transcription; translation; transport and stress tolerance.

\section{Primary metabolism \\ Secondary metabolism}

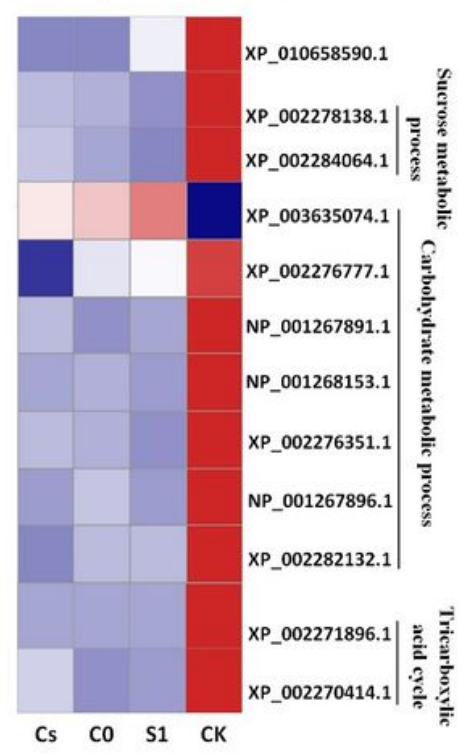

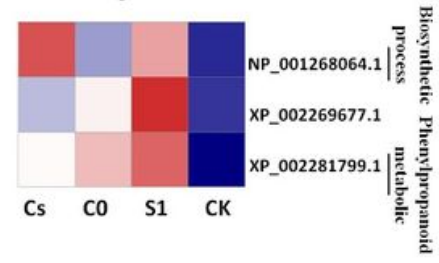

\section{Bio-signaling}

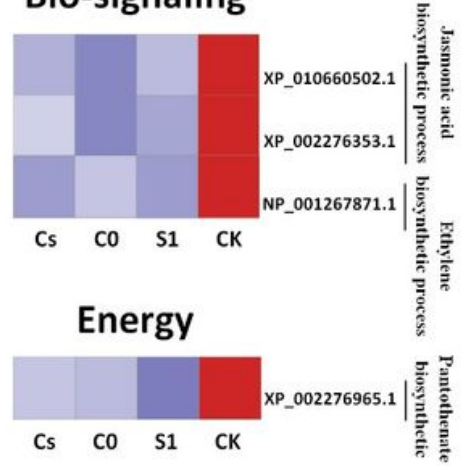

Stress tolerance

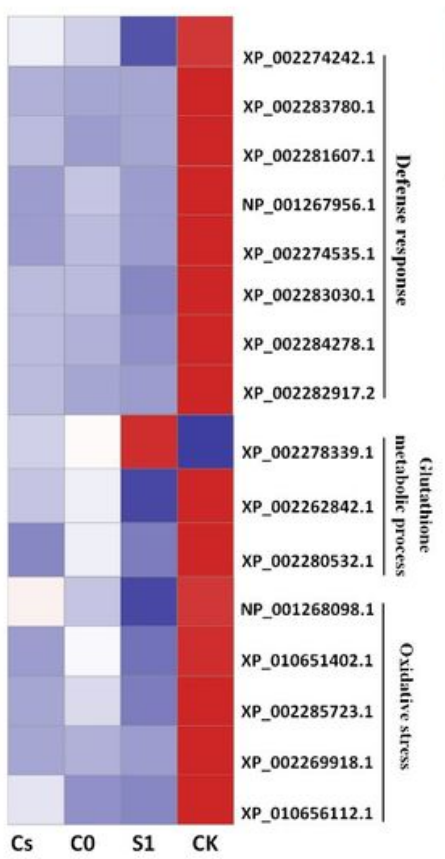

Transport

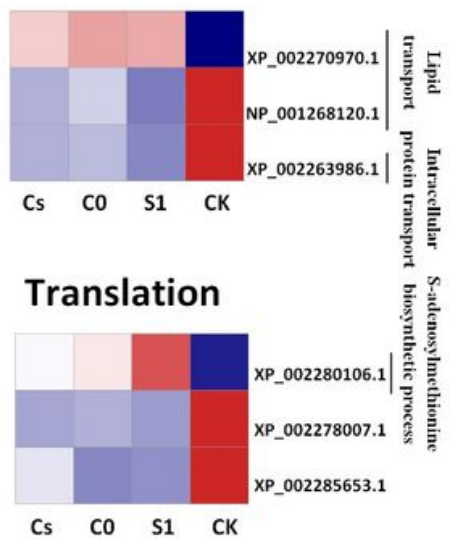

Figure 6

Heat map illustrating the relative protein expression at $\mathrm{Cs}, \mathrm{C} 0$ and $\mathrm{S} 1$ compared with $\mathrm{CK}$ based on the DEPs fold change (FC). Differentially expressed proteins have been categorized into primary metabolism; secondary metabolism; energy; bio-signaling; translation; transport as well as stress tolerance. 


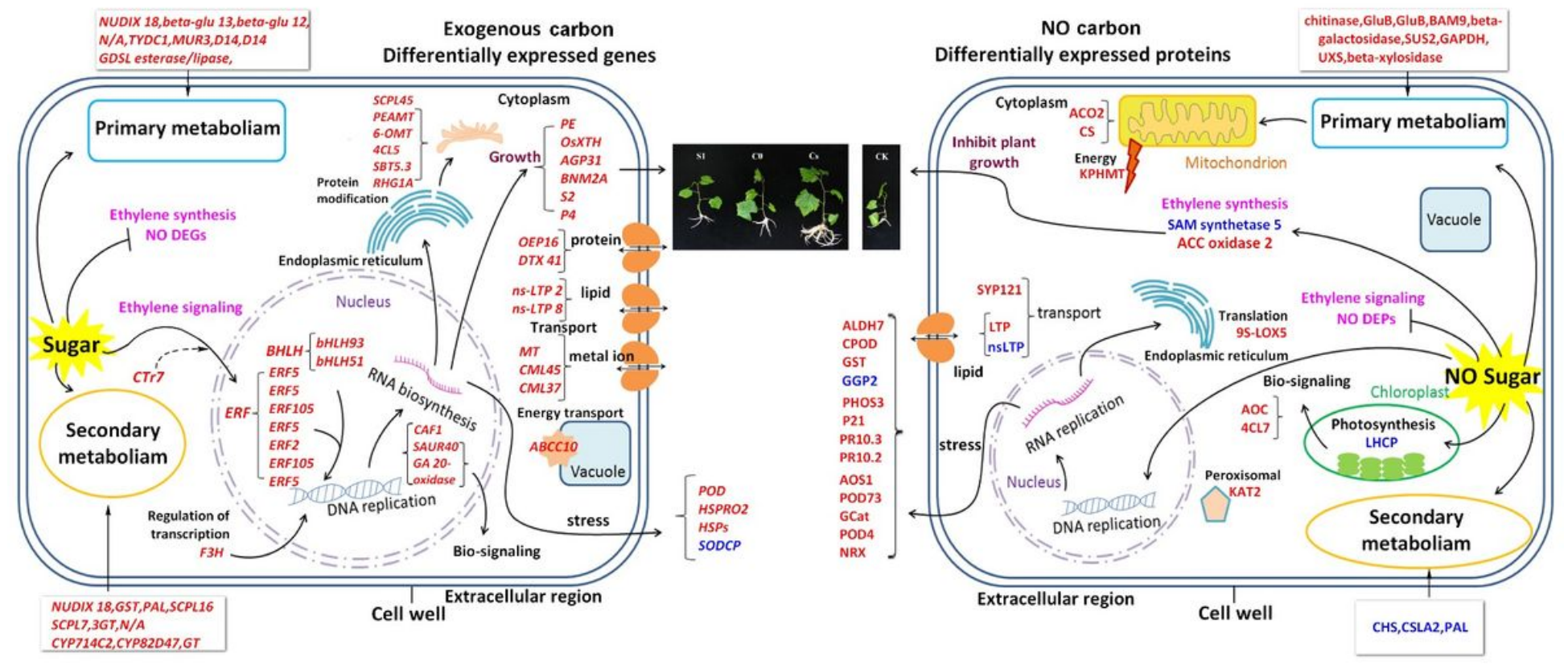

Figure 7

Effects of exogenous carbon on genes and proteins expression in grape plantlets in vitro. The DEGs or DEPs of red was up-regulated and blue was down-regulated.

\section{Supplementary Files}

This is a list of supplementary files associated with this preprint. Click to download.

- TableS4DescriptionandFoldChangeofDEPs.docx

- TableS2Summaryofsequencingdata.docx

- TableS3DescriptionandFoldChangeofDEGs.docx

- TableS1SequencesofprimeremployedinqRTPCRanalysis.doc 